BORDERS OF BELONGING 
This page intentionally left blank 


\section{BORDERS OF BELONGING}

STRUGGLE AND SOLIDARITY

IN MIXED-STATUS

IMMIGRANT FAMILIES

HEIDE CASTAÑEDA

STANFORD UNIVERSITY PRESS • STANFORD, CALIFORNIA 
Stanford University Press

Stanford, California

(O2019 by the Board of Trustees of the Leland Stanford Junior University. All rights reserved.

No part of this book may be reproduced or transmitted in any form or by any means, electronic or mechanical, including photocopying and recording, or in any information storage or retrieval system without the prior written permission of Stanford University Press.

Printed in the United States of America on acid-free, archival-quality paper

Library of Congress Cataloging-in-Publication Data

Names: Castañeda, Heide, author.

Title: Borders of belonging : struggle and solidarity in mixed-status immigrant families / Heide Castañeda.

Description: Stanford, California : Stanford University Press, 2019. | Includes bibliographical references and index.

Identifiers: LCCN 2018018752 | ISBN 9781503607217 (cloth : alk. paper)| ISBN 9781503607910 (pbk. : alk. paper) | ISBN 9781503607927 (epub)

Subjects: LCSH: Immigrant families-Texas_Lower Rio Grande Valley. | Immigrants_Family relationships-Texas_Lower Rio Grande Valley. | Illegal aliens_Family relationships-Texas-Lower Rio Grande Valley. | Immigrants-Texas-Lower Rio Grande Valley-Social conditions.

Classification: LCC JV7100 .C37 2019 | DDC 306.85086/912097644-dc23

LC record available at https://lccn.loc.gov/2018018752

Typeset by Westchester Publishing Services in 10/14 Minion Pro

Cover design by Rob Ehle

Cover photo: AP Images 